\title{
Major dinosaur discoveries in a nutshell
}

\author{
Daniel Madzia \\ Acta Palaeontologica Polonica 66 (2), 2021: 448-448 doi:http://doi.org/10.4202/app.00906.2021
}

Donald R. Prothero. 2019. The Story of the Dinosaurs in 25 Discoveries: Amazing Fossils and the People Who Found Them. 488 pp. Columbia University Press, New York. ISBN 9780231186025 (hardcover). Price $\$ 35.00 / £ 30.00$.

Daniel Madzia [daniel.madzia@gmail.com], Institute of Paleobiology, Polish Academy of Sciences, ul. Twarda 51/55, PL 00-818 Warsaw, Poland.

This is an open-access article distributed under the terms of the Creative Commons Attribution License (for details please see creativecommons.org), which permits unrestricted use, distribution, and reproduction in any medium, provided the original author and source are credited.

Fofif Full text $(258.0 \mathrm{kB})$ 